\section{Cuts at British Museum (NH)}

SIR-In 1939, a proposal by the trustees of the British Museum (Natural History) to move the best ornithological collection in the world from the famous Bird Room at South Kensington to an outlying branch at Tring caused a major outcry, for reasons summarized by one of the former 'supernumerary staff' who had worked there for 30 years, the late Dr D.A. Bannerman, who wrote " are visited and consulted by ornithologists of every nation, would automatically lose half their value through their inaccessibility . . . the contemplated move of the Bird Room from London will be greeted with dismay by 90 per cent of those with whom my work has brought me into contact".

The project was suspended for 30 years, until most of those who had objected were dead, but was then reintroduced so unobtrusively that local and international protests $^{2.3}$ came too late to stop it. There was excessive delay over the move ${ }^{4.5}$, which helped to discourage the remaining outside workers, by now treated by the growing professional staff as rather a nuisance, if not rivals, from undertaking the difficult journey to Tring, where there is now a shortage of local accommodation which has become very expensive. A large part of the egg collection was soon stolen over a period unnoticed, and the rest shuffled around ${ }^{6}$, since when increasing restraints have been placed upon visitors, who are no longer encouraged to assist with work on the collections.

The move to Tring might have been tolerable if what, in defiance of the informal tradition of the Bird Room, was renamed the 'Subdepartment of Ornithology' had continued to flourish, but it was one of the unspoken objections to the move that if the collections were exiled from the main museum, they might suffer disproportionately compared with other departments in hard times. Since 1980, four more or less distinguished and influential senior staff who retired have not been replaced, another is due to leave shortly, and it is said that the last two may soon be declared redundant as part of a general decision to abandon research on (of all things) cetaceans, birds, arachnids and coelenterates, leaving only three junior curators in the subdepartment to deal with the endless stream of enquiries from the public and to welcome distinguished foreign visitors.

This means the virtual end of organized research on bird systematics in Britain at a time of its explosive development as the result of the introduction of a variety of new ideas and techniques throughout the world, in which the staff of the subdepartment were beginning to play a more active role ${ }^{7}$. In consequence of the default of the past management, the authors of the current vast authoritative handbook on the birds of the western Palearctic, edited in Britain ${ }^{8}$, have already had to go abroad for their systematics, which were provided for their predecessors through the private enterprise of a former Lord Rothschild from the same museum at Tring. It seems time that the current performance behind the turnstiles and showcases of this national institution turned scientific Disneyland in relation to its past traditions and promises received more public scrutiny.

University of Aberdeen,

W. R. P. BOURNE

Department of Zoology,

Tillydrone Avenue,

Aberdeen AB9 $2 T N, U K$

1. Ibis 82, $183-185,382-385,575-577(1940)$

2. Allason, J. The Times 30 January 1969.

Noture 221, 1094, 1197; 222,605-606; 223,430 (1969)

Nature 239, 118 (1972)

Br. Birds 65, 492 (1972)

The Times 1 May 1980.

Knox, A. Br. Birds 81, 206-211 (1988)

. Cramp, S. et al. (eds) Handbook of the Birds of Europe, the Middle East and North Africa (Oxford University Press, 1977 on, 5 vols, continuing)

SIR-The curatorial staff of the American Museum of Natural History view with alarm the effects of recent cutbacks of programme and staff at the British Museum (Natural History). The latest decisions, relegating the programmes in coelenterates, arachnids and birds to a "care and maintenance mode", has eliminated research personnel in these areas, leaving these collections of inestimable scientific worth in the care of technicians who may not, in all cases, be professionally trained biologists.

What is at stake here is nothing short of mankind's understanding of the current diversity of life. In recent years, budgeting and funding priorities, in conjunction with basic trends in biological research generally, have seen a steady concentration of high-calibre research in systematic biology increasingly in large private or government-sponsored natural history museums. As erosion of collection support and collection-based research has continued at universities, museums have struggled to take up the slack. And while systematics is vigorously pursued at relatively fewer kinds of institutions, it is also true that the intensity and calibre of such research has never been higher since the days of Linnaeus. Prominent among those institutions with the very highest quality of systematics research has been

Paradoxically, while support of even our finer research institutions in systematics continues to be threatened, the public at large has seldom if ever been more aware of the need for a deep underthe $\mathrm{BM}(\mathrm{NH})$ standing of the diversity and connectedness of the living biota. The collections at the $\mathrm{BM}(\mathrm{NH})$, the fruits of worldwide scientific collecting for well over a hundred years, constitute one of a handful of records of the state of the living world as it is - and was - just at the onset of the current wave of ecosystem and species loss that is now taking place. Simply put, such collections are irreplaceable.

Biological collections such as those of the $\mathrm{BM}(\mathrm{NH})$ are not sentimental memorabilia of a bygone era of empire and exploration. They are our only concrete source of information about a living world that is fast disappearing. It is no extravagant luxury to maintain them - and to do so properly, under the aegis of a highly skilled and thoroughly dedicated research staff. It is, instead, a vital necessity. We urge the administrative powers that be to reconsider their decisions, and other similar plans that may be in the offing. And we urge the British public to consider whether the relatively modest sums to be saved are worth the sacrifice in commitment to preserving on of the finest sources of information about the living world.

Gareth J. Nelson

Niles EldRIDGE

George E. Harlow

American Museum of Natural History,

Central Park West at 79th Street,

New York, NY 10024-5192, USA

\section{India and China}

SIR-Contrary to the comments you published earlier (Nature 331, 384; 1988), specific comparisons would reveal that India has indeed surpassed China in most fields.

The Chinese revolution stopped some three decades back, mostly through the redistribution of wealth, to provide a bowl of food, shelter and basic education, to its population at large. That too was accompanied by 50 million or more dead and mass persecutions by Chinese authorities, in contrast with the stone-age liberty that has hampered the development of what is needed most in India - a sense of national identity.

In fact, economic development was just not possible under Mao, who frowned on the notion of profit and distrusted the intellectual community to the extent that professional training all but stopped after the 1960 s cultural revolution. The existence of revolutionary cadres placed by Mao at all levels of party hierarchy is one of the most difficult political obstacles for the current leadership in changing Chinese society.

The history of development is actually less than a decade old since China adopted the so-called open-door policy. Chinese in Beijing are fond of boasting about something as simple as the first luxury hotel being constructed by purely indigenous 